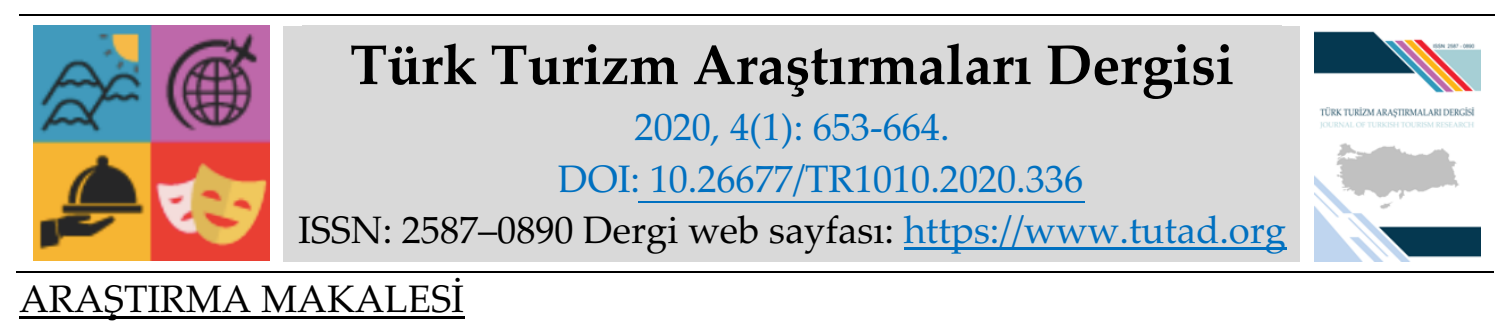

\title{
Rekreasyon Faaliyetleri Kapsamında Etkinlik ve Festivallerin Destinasyon İmajına Etkisi
}

Dr. Öğr. Üyesi Fatih ERCAN, Zonguldak Bülent Ecevit Üniversitesi, Karadeniz Ereğli Turizm Fakültesi, Zonguldak, e-posta: fatih.ercan@beun.edu.tr

ORCID: https://orcid.org/0000-0001-6469-3000

Dr. Öğr. Üyesi Makbule CiVELEK, Zonguldak Bülent Ecevit Üniversitesi, Karadeniz Ereğli Turizm Fakültesi, Zonguldak, e-posta: makbule.civelek@beun.edu.tr

ORCID: https://orcid.org/0000-0002-3997-6508

Öz

Rekreasyon bireylerin boş zamanlarında gönüllü olarak katıldığı faaliyetleri kapsamaktadır. Bu faaliyetler turizm bazında ele alındığında çeşitlilik arz etmektedir. Animasyonlardan, şehir turlarına, müze ziyaretlerinden temalı parklara, festivallerden spor etkinliklerine kadar geniş bir yelpazeyi oluşturmaktadır. Bu çalışmada rekreatif faaliyetlerden biri olan etkinlik ve festivaller ele alınmıştır. Etkinlik ve festivaller destinasyonların imajına doğrudan etki etmektedir. Bunun yanı sıra destinasyonların değişimi ve dönüşümüne de doğrudan katkı sağlamaktadır. Bu etkiler ekonomik, sosyo-kültürel ve tanıtım olarak sıralanabilir. Özellikle yerel halkın sosyal gelişiminde, yöresel ürünlerin tanıtımında, geleneklerin sürdürülmesinde ve gelecek kuşaklara aktarılmasında etkinlik ve festivallerin rolü önemlidir. Bu çalışmanın temel amacı Karadeniz Ereğli ilçesinde yapılan Sevgi Barış ve Dostluk Festivali'nden hareketle etkinlik ve festivallerin destinasyon imajına etkilerini saptamaktır. Çalışmanın amacı doğrultusunda festivalde görev almış ya da etkileşimde bulunmuş uzman kişilerle yarı yapılandırılmış görüşme formları aracılığıyla görüşmeler yapılmıştır. Yapılan görüşmeler ile festivallerin sosyo-kültürel yapı, ekonomik yapı, tanınırlık, imaj ve tanıtım unsurları bakımından destinasyon imajına olumlu etkileri olduğu tespit edilmiştir.

Bu çalışma, 11-13 Ekim 2019 tarihlerinde düzenlenen “IV. International Social, Human and Administrative Sciences Congress" de sunulan ve kongre bildirileri kitabında yayınlanan “Etkinlik ve Festivallerin Şehirlerin Turizm Potansiyelini Geliştirmedeki Rolü: Karadeniz Ereğli Örneği” isimli çalışma genişleterek oluşturulmuştur.

Anahtar Kelimeler: Etkinlik Turizmi, Festivaller, Destinasyon İmajı, Sevgi Barış ve Dostluk Festivali.

Makale Gönderme Tarihi: 05.11.2019

Makale Kabul Tarihi: 18.01 .2020

Önerilen Atıf:

Ercan, F. ve Civelek, M. (2020). Rekreasyon Faaliyetleri Kapsamında Etkinlik ve Festivallerin Destinasyon İmajına Etkisi, Türk Turizm Araştırmaları Dergisi, 4(1): 653-664.

(C) 2020 Türk Turizm Araştırmaları Dergisi. 


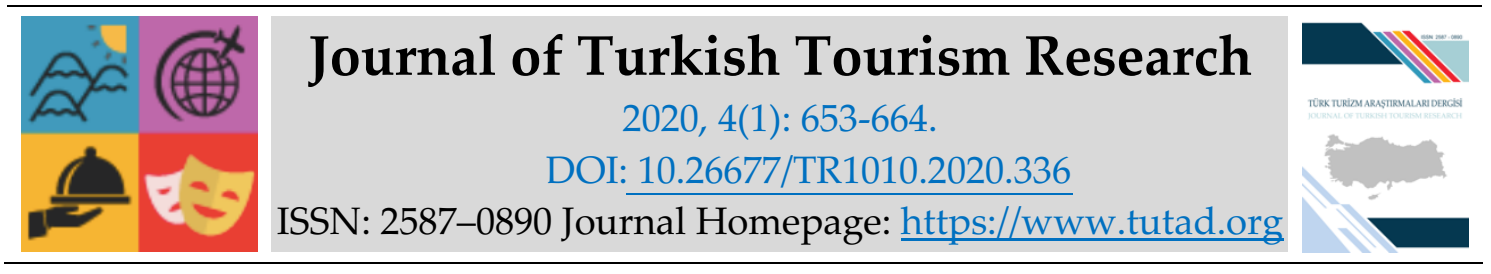

\title{
$\underline{\text { RESEARCH PAPER }}$
}

\section{Effects of Events and Festivals on Tourism Potential in Recreation Activities}

Assistant Prof. Dr. Fatih ERCAN, Zonguldak Bülent Ecevit University, Karadeniz Ereğli Faculty of Tourism, Zonguldak, e-mail: fatih.ercan@beun.edu.tr

ORCID: https://orcid.org/0000-0001-6469-3000

Assistant Prof. Dr. Makbule CiVELEK, Zonguldak Bülent Ecevit University, Karadeniz Ereğli Faculty of Tourism,_Zonguldak, e-mail: makbule.civelek@beun.edu.tr

ORCID: https://orcid.org/0000-0002-3997-6508

\begin{abstract}
Recreation includes activities that individuals participate voluntarily in their spare time. These activities are diverse in terms of tourism. They range from animations, city tours, museum visits to theme parks, festivals and sports events. In this study, one of the recreational activities and festivals are discussed. Events and festivals have a direct impact on the image of destinations. Activities have a direct impact on the change and transformation of destinations. These impacts can be listed as economic, socio-cultural and publicity. The role of events and festivals is especially important in the social development of local people, promotion of local products, maintenance of traditions and transferring to future generations. The main problem of this study is to determine the effects of the activities and festivals from the Love Peace and Friendship Festival held in Ereğli district of Karadeniz. For the purpose of the study, face-to-face interviews were conducted with semi-structured interview forms with experts who worked or interacted at the festival. With the interviews, it was seen that the festivals had positive effects on the district in terms of socio-cultural structure, economic structure, recognition, image and promotional elements.
\end{abstract}

Keywords: Event Tourism, Festivals, Destination Image, Love Peace and Friendship Festival.

Received: 05.11.2019

Accepted: 18.01 .2020

\section{Suggested Citation:}

Ercan, F. and Civelek, M. (2020). Effects of Events and Festivals on Tourism Potential in Recreation Activities, Journal of Turkish Tourism Research, 4(1): 653-664.

(C) 2020 Türk Turizm Araştırmaları Dergisi. 


\section{Gíriş}

Rekreasyon, bireylerin gündelik yaşamlarının dışına çıkarak boş zaman faaliyetlerini etkin bir şekilde değerlendirme sürecidir. Bireyler rekreasyon faaliyetlerine gönüllü olarak katılarak yenilenme sürecine katkı sağlamaktadır. Rekreatif faaliyetler çeşitlilik göstermekle birlikte bu çalışmanın temel konusunu oluşturan etkinlik ve festivaller özelinde ele alınması da mümkündür.

Etkinlik ve festivaller destinasyonların bilinirliliğinin sağlanmasına olanak tanırken, turistik imaj oluşturma aşamasında da rol oynamaktadır. Etkinlik ve festivallerin olduğu zamanlarda sosyal ve kültürel aktiviteler aracılığıyla insanların kaynaşmasını, birlikteliğin sağlanmasını ve hoşgörü ortamının oluşmasını da beraberinde getirmektedir. Etkinlik ve festivaller, farklı kültür ve yapıdaki insanları bir araya getirerek ortak bir paydada buluşmalarını sağlamaktadır. Bu sebeple etkinlik turizmi kapsamındaki etkinlikler ve festivallerin kavramsal olarak incelenmesi önemli bir gereklilik olarak görülebilir.

Etkinlik ve festivaller sosyal yaşama katkısı dışında ekonominin gelişmesine ve çeşitlenmesine etki etmektedir. $\mathrm{Bu}$ faaliyetlerin yapıldığı dönemde ziyaretçi sayısının artmasıyla birlikte konaklama sektöründen, yiyecek içecek sektörüne, ulaşım sektöründen eğlence hizmetlerine kadar katma değer yaratmaktadır. Yaratılan katma değer etkinlik ve festivallerin yerel halk için önemini göstermektedir.

Etkinlik ve festivaller destinasyonların imajı üzerinde etkili olmaktadır. Destinasyonların tanınırlığı ve bilinirliği bu faaliyetler aracılığı ile şekillenmektedir. Bunun yanı sıra pozitif imaj oluşturma ve destinasyonunun pazarlama faaliyetlerine yön verme amaçlarıla etkinlik ve festivallerden yararlanılmaktadır. Kısa sürede daha fazla kişiye ulaşmayı sağlayan etkinlik ve festivaller yöresel ürünleri tanıtma, yerel halka katkı sağlama, sosyo-kültürel gelişim ve paylaşımın artması gibi unsurlar bakımından ön plana çıkmaktadır.

Çalışma, Karadeniz Ereğli'de geleneksel olarak düzenlenen Sevgi Barış ve Dostluk Festivali'nin ilçenin destinasyon imajı üzerine etkilerini tespit etmeyi amaçlamaktadır. Bu amaç doğrultusunda destinasyon imajını ortaya koyabilecek alt unsurlar belirlenmiştir. Sosyo-kültürel unsurlar, ekonomik unsurlar, tanınırlık ve bilinirlik destinasyon imajını tespit etme amacı ile kullanılmıştır.

Çalışma iki temel bölümden oluşmuştur. İlk bölümde destinasyon imajı, etkinlik ve festival kavramlarına değinilirken turizm bağlamında etkinlik ve festivallerin önemi de vurgulanmıştır. Kavramsal çerçevede konuyla ilgili teorik bilgilere ve yapılan çalışmalara yer verilmiştir. İkinci bölüm çalışmanın metodoloji bölümü olup araştırma yöntemi ve bulgularından oluşmaktadır.

\section{KAVRAMSAL ÇERÇEVE}

\section{Rekreasyon Faaliyetleri Kapsamında Etkinlik Kavramı ve Sınıflandırılması}

Tören, kutlama, festival, spor, sanat ve benzeri faaliyetleri kapsayan etkinlik kavramını destinasyonların bir çekiciliği olarak tanımlayan Çelik ve Çetinkaya (2013), etkinliklerin turistik tüketicilere yerel kültürü tanıma, toplumsal ve kültürel anlamda bilgi sağlama yönüne dikkat çekmektedir. Timur vd. (2014) de benzer bir görüşü savunarak, etkinliklerin sosyo-kültürel ve ekonomik anlamda faydası üzerinde durmuştur. Getz (2008: 405) etkinlikleri turizm olgusuyla birlikte ele alarak, etkinlik turizmini olumlu bir destinasyon imajı oluşturmayı sağlayan, pazarlama ve markalaşmayı da içine alan turizme yönelik planlanmış bütün etkinlikler olarak tanımlamaktadır. 
İlgili literatürde etkinlikler araştırmacılar tarafından çeşitli şekillerde sınıflandırılmıştır. Babacan ve Göztaş (2011) etkinliklerin kültür, spor, politik ve iş dünyasına yönelik etkinliklerden, mega etkinliklere, EXPO'lara, festivallere, küçük çaplı özel etkinliklere, toplantılara ve yarışmalara kadar uzanan alan olduğunu vurgulamıştır. Getz (2008: 404) etkinliklerin önemli bir turizm motifi olduğuna dikkat çekmekte, içeriklerine, amaç ve kapsamlarına göre etkinliklerin farklılaştıklarını belirtmektedir. Yazar, bazı etkinliklerin halk kutlamaları şeklinde olduğunu, bazılarının ise yarışma, eğlence, iş veya sosyalleşme amaçlı planlanan etkinlikler olduğunu vurgulamaktadır. Genel olarak ise etkinlikler; boyutuna, içeriklerine, ulusal ya da uluslararası olma gibi özelliklerine göre üçe ayrılmaktadır. Bunlar; mega etkinlikler, hallmark etkinlikler ve yerel etkinliklerdir.

Mega Etkinlikler: Düzenleyici şehir ve ülkeler için soyut ya da somut çeşitli etkileri olan, büyük kitlelere hitap eden, uluslararası boyutta öneme sahip, uzun süreli etkinliklerdir (FİFA Dünya Kupası, World Expo, Olimpiyatlar, vb.) (Arnegger ve Herz, 2016: 76).

Hallmark Etkinlikler: Daha dar kapsamlı, tek seferlik ya da daha kısa bir zaman periyodu içerisinde gerçekleşen, destinasyon imajı ve çekiciliğini artırmak için planlanan etkinliklerdir (Getz ve Page, 2016: 598).

Yerel Etkinlikler: Büyüklük esasına göre en dar coğrafi alanı temsil etmektedir. Bununla birlikte alanlarına göre etkinlikler kültürel, sportif etkinlikler, fuarlar, festivaller, işletme etkinlikleri, sosyal amaçlı etkinlikler ve ödül törenleri şeklinde de sınıflandırılabilirler (Timur vd., 2014: 59).

\section{Festival Kavramı ve Önemi}

Etkinlik turizmi içerisinde yer alan festivaller geniş bir tanımla ile; "insanlık tarihi kadar eskiye dayanan, turist çekmek, yörenin kültürünü aktarmak, rahatlama ve eğlence aktivitelerine alternatif oluşturmak" (Boğan vd., 2017:12) amaçlarıyla "yerel idare ya da yerel halk tarafindan tarihi önceden belirlenerek yapılan" (Erdem vd., 2018), "büyük veya küçük birçok şehirde ulusal ya da uluslararası boyutta gerçekleştirilen", “düzenlendiği yörenin öz değerlerini, kimliğini sergileyen" (Yıldırım vd., 2017: 241) faaliyetler olarak belirtilmiştir.

Festivallerin temel amacı yörenin simgesi haline gelerek gelenekselleşmiş, sürekliliği sağlanarak yeni nesillere aktarılması ve yaşatılmasından hareketle bilim, sanat, oyun ve diğer sosyal alanlarda düzenlenen ulusal veya uluslararası gösteri ya da şenliklerdir (Erdem vd., 2018: 228). Congcong (2014: 53) ise festivallerin geleneklerin yaşatılması ve nesilden nesile aktarılması ihtiyacından ortaya çıkan sosyal bir faaliyet olduğunu savunmaktadır. Benzer bir görüş Sullivan ve Jackson (2002: 325) tarafından ortaya atılmıştır. Yazarlara göre, festivaller aracılığıyla destinasyonların tanınması, kültürlerin aktarılması ve çevresel gelişim sağlanması mümkündür. Festivaller, topluluklar arasında yakınlaşma sağlayarak ülkenin tanıtımına ve diğer kültürel değerlerin de dolaylı olarak tanitılmasına katkı sağlar. Belirli bir alanda ve zamanda, görsel performans ve ürünlerin sunulması ile gerçekleştirilen bu etkinlikler bütünü, ulusal veya uluslararası boyutta gerçekleşebilir (Penpece, 2014: 193).

Mihajlovic ve Vidak'a (2017: 231) göre, günümüzde turistlerin tercihleri standart ürünlerden daha spesifik, yenilikçi turistik ürünlere doğru yönelmektedir. Yazarlara göre, kutlamalar, festivaller, karnavallar, kültürel etkinlikler gibi daha ilgi çekici unsurlar tanıtım faaliyetlerinde ve turizm pazarlamasında son yıllarda ön plana çıkmaya başlamaktadır. Burada, etkinlik ve festivallerin turizmin gelişimine ve bir şehrin/yörenin tanıtımına olan katkısı vurgulanmaktadır. 


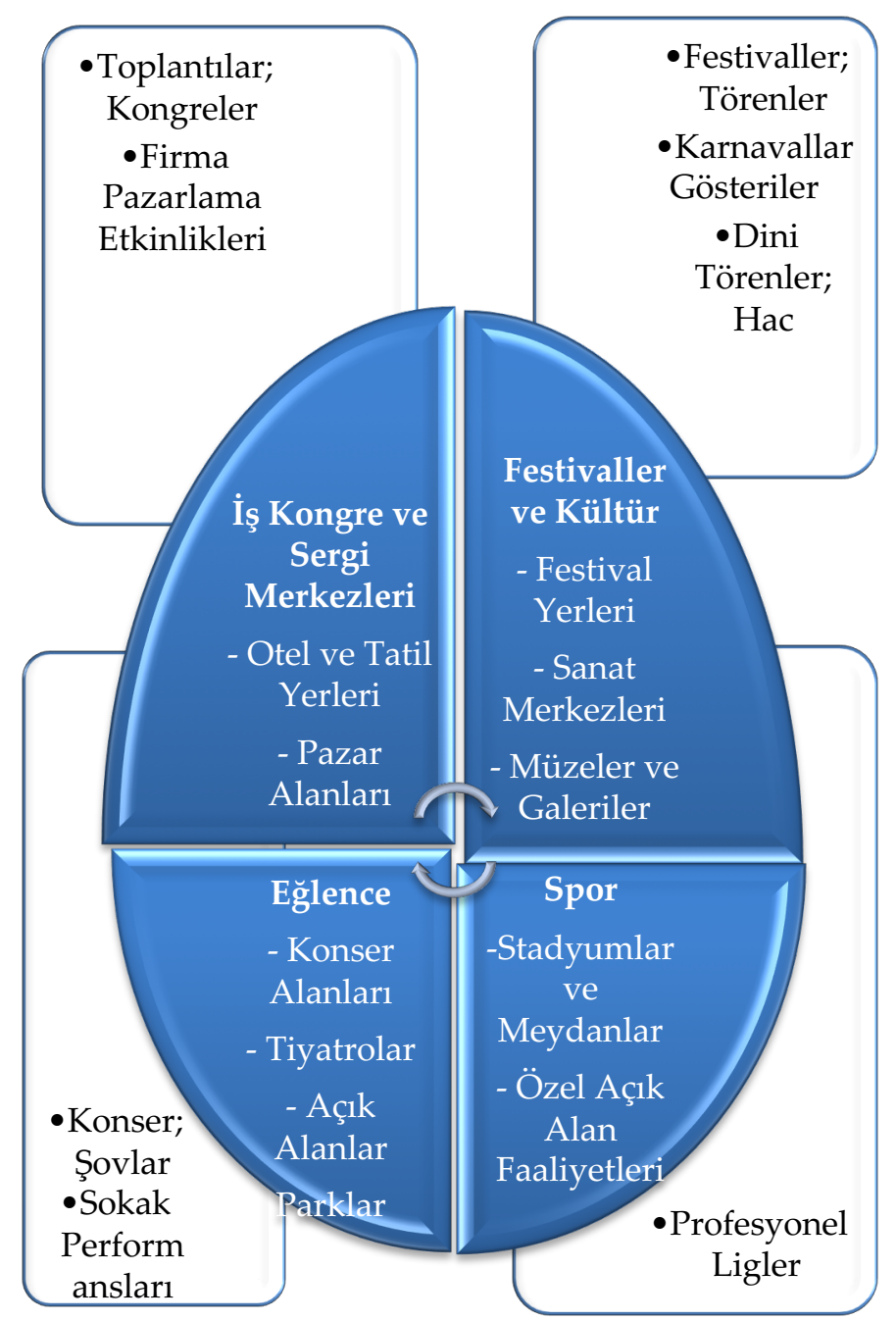

Şekil 1: Turizm-Etkinlik Perspektifinden Planlanmış Açık Alan Etkinlikleri ve Etkinlik Yerleri Kaynak: Getz ve Page, 2016: 594.

Festivaller, dünya genelinde insanlar arasındaki dostluğu pekiştirirken, aynı zamanda tanışılan yeni kültürlere ve yaşamlara duyulan merakı körükleyerek insanları yeni yerler görmeye teşvik etmektedir (Çulha, 2008: 1828). Festivaller, yerel halkın ve ziyaretçilerin ilgisini çekerek katılımını sağlamakta, düzenlendiği şehre, yöreye yönelik bir turist akışı oluşturmaktadır. Artan bu talep iş hacmini artırarak bölge ekonomisine katkı sağlamakta ve bölgesel kalkınmayı, gelişimi hızlandırmaktadır. Ekonomik etkilerinin yanı sıra, insanları birbirine yakınlaştırıcı, bütünleştirici etkileri, sosyalleşmeyi artırma, gelenek ve görenekleri, kültürü paylaşma ve yaşatma gibi etkinlik ve festivallerin sosyo-kültürel etkilerinden söz etmek mümkündür.

Günümüzde festivaller, geçmişe göre çok daha çeşitli ve büyük çaptadır. Gelişmiş ülkelerde çeşitli türden festivallere yapılan yatırımlar, verilen önem ve etkin tanıtım çabaları, diğer bir ifadeyle, bu etkinliklerin iyi pazarlanması ile festivaller farklı ülkelerden binlerce katılımcıyı cezbetmekte ve ev sahibi ülkeye önemli gelir de sağlamaktadır (Penpece, 2014: 206). Festivaller, düzenlendikleri bölgelere hem renk ve canlılık getirir hem de bölge halkına ayrıcalıklar ve bazı sosyal faydalar sağlamaktadırlar. Bunun dışında, yapılan festivallerin çokluğu bölge halkının ticari faaliyetlerini ve yatırımcıların etkinliklerini arttırması bakımından önemli bir yer teşkil eder (Tümbek Tekeoğlu ve Gökseven, 2019: 345). 


\section{Destinasyon İmajı Kapsamında Etkinlik ve Festivaller}

Turizm bağlamında etkinlik ve festivallerin, çekicilik oluşturarak düzenlendiği destinasyonda turist ziyaretlerini artırdığı, turizm potansiyelini geliştirdiği (Felsenstein ve Fleischer, 2003, Çulha, 2008; Karabağ vd., 2011; Nagy ve Nagy, 2013; Mohammad, 2014; Penpece, 2014), sosyokültürel yapıyı şekillendirdiği, ekonomik katkı sağladığı (Sullivan ve Jackson, 2002; Bogan vd., 2017; Robertson vd., 2009; Okech, 2011; Yolal, 2017; Laing, 2018) ve destinasyon imajını etkilediği (Kim ve Uysal, 2003; Cizmic ve Causevic, 2017) yapılan farklı araştırmalarda ortaya konulmaktadır.

Kim ve Uysal (2003), etkinlik ve festivallerin destinasyonlar için önemli bir çekicilik unsuru olarak hizmet ettiğini ve ziyaretçilerin benzersiz deneyimler yaşamasını sağladığını belirtmektedirler. Yazarlar, etkinlik ve festivallerin, ek gelir sağlama, vergi geliri elde etme gibi hem somut hem de toplumun manevi değerlerini, duygularını yaşatma, olumlu destinasyon imajı oluşturma gibi soyut faydalar sağlayacağını ifade etmektedirler. Robertson vd. (2009) etkinlik ve festivallerin, düzenlendiği şehrin, yörenin gelişimine katkı sağlayan bir kültürel üretim ve deneyim şekli olduğunu belirterek hem sosyo-kültürel hem de ekonomik önemine vurgu yapmaktadır. Sullivan ve Jackson (2002) yaptıkları araştırmada festivallerin yerel ekonomiye katkı sağlayacağı üzerinde durmuştur. Festivallerin destinasyona ve yerel ekonomiye sürdürülebilir katkı sağlayabilmesi için öneriler getirmiştir.

Etkinlik ve festivallerin destinasyon imajı oluşturmadaki önemi, ilgili literatürde yapılan çalışmalarda sıklıkla ele alınan hususlardan biri olarak dikkat çekmektedir. Cizmic ve Causevic (2017) doğru bir biçimde planlanmış ve organize edilmiş turizm etkinliklerinin sadece bölge ekonomisine katkı sağlamayacağını, aynı zamanda destinasyon imajı oluşumunda da önemli bir etkiye sahip olacağını belirtmektedirler. Benzer şekilde Kim ve Uysal (2003) etkinlik ve festivallerin destinasyon imajını geliştirmedeki öneminden bahsetmekte, doğru şekilde planlandığı takdirde olumlu bir destinasyon imajı oluşumunda etkinlik ve festivallerin katkısının büyük olacağının altını çizmektedirler.

Bogan vd., (2017) günümüzde destinasyonların turizmi geliştirmek amacıyla, büyük etkinlik ve festivallere ev sahipliği yapmak için birbirileri ile yarış halinde olduklarını ve bu organizasyonlara büyük yatırımlar gerçekleştirdiklerini belirtmektedirler. Yazarlar, turizmin gelişimi, ekonomik büyüme, toplumsal bağları güçlendirme, yerel halk ve turistlere kültürü tanıtma, uluslararası düzeyde tanıtım ve daha iyi bir şehir imajı oluşturmayı etkinlik ve festivallerin organize edilmesinin en önemli sebepleri arasında göstermektedirler. Dolayısıyla, şehirlerin turizm potansiyelini geliştirmede, talebi artırmada ve şehir turizminin canlandırılmasında etkinlik ve festivalleri önemli bir faktör olarak değerlendirmek mümkündür.

\section{YÖNTEM}

\section{Araştırmanın Amacı ve Önemi}

Araştırmanın amacı Karadeniz Ereğli'de 2019 yılı itibariyle 21.'si düzenlenen Sevgi Barış ve Dostluk Festivali özelinden hareketle etkinlik ve festivallerin turizm potansiyeli ve destinasyon imajına etkisini saptamaktır. Bu amaç doğrultusunda festivalin destinasyon imajına ve turizm potansiyeline ilişkin katkıları araştırılmıştır. Araştırma Karadeniz Ereğli özelinde ele alınması ve ilçede yapılan festivalin etkilerini ortaya koyacak olması gibi sebeplerden dolayı önem taşımaktadır. Aynı zamanda festivalin geleneksel bir hal alması araştırmanın genel geçer sonuçlara ulaşması açısından önemlidir. İlçede geleneksel hale gelen festivalin destinasyon imajı üzerindeki olası etkilerinin literatürde henüz çalışılmamış olması da özgünlük taşımaktadır. 


\section{Araştırma Kapsamı}

Araştırma, Karadeniz Ereğli'de geleneksel hale gelen, 5 Temmuz 2019-7 Temmuz 2019 tarihleri arasında gerçekleşen Sevgi Barış ve Dostluk Festivali'ni kapsamaktadır. Genel itibari ile saat 9.00' da başlayan etkinlikte çeşitli faaliyetler düzenlenmiştir. Etkinlikler 3 gün sürmüştür. Bu etkinlikler kapsamında doğa yürüyüşü, su sporları, mim sanatçılarının gösterileri, seramik heykel gösterisi, halk dansları, açık hava resim sergisi, gemi maketleri sergisi, tarihi yerlerin ziyareti, çocuk tiyatroları, turnuva ve yarışmalar, futbol maçları, amatör ve profesyonel sanatçıların yer aldığı konserler yapılmıştır.

\section{Araştırma Verilerinin Toplanması}

Araştırma verileri 10-17 Temmuz 2019 tarihleri arasında festival bitiminden sonra toplanmıştır. Veriler, 2019 yılında Karadeniz Ereğli'de 21.'si düzenlenen Sevgi Barış ve Dostluk Festivali'nde görev almış uzman kişilerden görüşme yoluyla elde edilmiştir. Uzman kişilerin seçiminde kamu kurumlarında ve sivil toplum kuruluşlarında çalışanlar tercih edilmiştir. Çalışmaya dahil edilen örneklemden randevular alınarak çalışma konusu ve amacı hakkında bilgiler verilmiştir. Tüm görüşmeler izinler doğrultusunda ses kaydına alınmıştır. Araştırma kapsamında alanında uzman 9 kişiye, 6 soru yönlendirilmiştir. Görüşmelerin ortalama süresi 53 dakikadır.

\section{Araştırma Yöntemi}

Araştırma kapsamında nitel yöntemlerden biri olan görüşme kullanılmıştır. Araştırmada derin görüşme ile alanında uzman kişilerden veri toplanmıştır. Derin görüşme, görüşmecinin cevaplayanlarla teke tek mülakat yapmasıdır. Bir görüşme bitmeden diğerine geçilmez. Derin görüşme, cevaplayıcıların güdü, inanç, tutum ve duygularını öğrenmek maksadıyla yapılır temel amaç, herhangi bir sınırlama olmaksızın eleştiri ve görüşlere doğrudan ulaşmaktır (Nakip, 2013: 123). İlgili literatür incelenerek araştırmanın temel amacı doğrultusunda yarı yapılandırılmış sorular hazırlanmıştır. Yarı yapılandırılmış sorular aracılığıyla uzman kişilerden elde edilen veriler yüz yüze toplanmıştır. Araştırmada yöntem olarak görüşmenin seçilmesinin sebebi, araştırma sorularının derinlemesine bilgi gerektirmesidir. Uzman kişilerin tercih edilme nedeni ise etkinlikler ve festival hakkında eksiksiz bilgiye ulaşmaktır

Araştırma soruları iki ana bölümden oluşmaktadır. İlk bölüm demografik özellikleri belirlemeye yönelik hazırlanmıştır. İkinci bölüm ise katılımcıların festivale ilişkin görüşlerini belirlemeye yöneliktir. Bu bölümün soruları festivalin sosyo-kültürel ve ekonomik etkilerini ortaya koymaya dönükken ilçenin turizm potansiyeline, imajına ve tanınırlığına katkısı da araştırılmıştır. Bunun yanı sıra festivalin destinasyon için önemi ve pazarlama faaliyetleri de tespit edilmeye çalışılmıştır. Araştırma kapsamında görüşme yapılan katılımcılara yönlendirilen yarı yapılandırılmış sorular aşağıdaki gibidir:

- Karadeniz Ereğli'de etkinlik (spor müsabakaları, yarışmalar, konserler) ve festivallerin sosyo-kültürel açıdan önemini nasıl yorumlarsınız?

- Karadeniz Ereğli'de etkinlik ve festivallerin ilçe ekonomisi açısından önemi nedir?

- Karadeniz Ereğli'de yapılan etkinlik ve festivaller ilçede turizmin gelişimine nasıl bir katkı sağlamaktadır?

- Etkinlik ve festivallerin Karadeniz Ereğli destinasyon imajı üzerindeki etkileri sizce nelerdir?

- Karadeniz Ereğli'nin tanıtımında ilçedeki etkinlik ve festivallerin yeri ve önemi nedir? 
- Etkinlik ve festivallerin tanıtım ve pazarlama faaliyetlerinde kullanılan iletişim araçlarını yeterli buluyor musunuz?

\section{BULGULAR ve TARTIŞMA}

Araştırma kapsamında görüşülen 9 kişiden 7'si erkek 2'si kadındır. Görüşme yapılanların ortalama yaşları 47,3'tür. Görevleri dernek başkanı (görüşmeci 1), resmi bir kurumda basın başkanı (görüşmeci 2), resmi bir kurumda kültür koordinatörü (görüşmeci 3), resmi bir kurumda sosyal işler müdürü (görüşmeci 4), tarih öğretmeni (görüşmeci 5), iş adamları derneği şube müdürü (görüşmeci 6), gazeteci (görüşmeci 7), dernek başkanı (görüşmeci 8) ve resmi bir kurumda yazı işleri müdürü (görüşmeci 9) olmak üzere değişkenlik göstermiştir. Tüm katılımclar üniversite mezunudur.

\section{Festivallerin Sosyo-Kültürel Etkisi}

Katılımcların tamamı festivallerin sosyo-kültürel yapıyı olumlu yönde etkileyerek sosyal yaşamı şekillendirdiğini belirtmiştir. Katılımcıların verdikleri yanıtlar derlendiğinde kültürel hayatı zenginleştirdiği, birlik ve beraberliği sağladığı, kaynaşma ve bütünleşme sağladığı, kırsal kesimde yaşayan kişilerin de etkinliklere katılarak kültür alışverişi sağladığı yönünde olmuştur. 2 katılımcı ise özellikle gençlerin ve çocukların festival boyunca yapılan etkinlik ve faaliyetlerden pozitif yönlü çıkarımlar yaptıklarını gördüklerini, ressamlar, müzisyenler, mim sanatçıları ve heykeltıraşlardan ufuklarının açıldığını eklemiştir.

“...Kdz. Ereğli'de düzenlenen festivallerin, konserlerin ve spor aktivitelerinin şehrin sosyo-kültürel hayatının zenginleşmesi açısından önemi büyük. Köylerde yaşayan halkın merkezde düzenlenen aktiviteye katılması onların sosyal hayatlarımı zenginleştirmekte ve sosyalleşmesini sağlamakta" (Görüşmeci 9).

"...Festivalleri, farklı demografik yapılardan şehre gelen insanların kaynaşma ve kültür alışverişi platformu olarak görüyorum" (Görüşmeci 4).

“...Festival sosyal ve kültürel yapıyı inanılmaz etkiliyor. Gençler ve çocuklar gördüklerini kendilerine uyarlamaya çalışıyor. Sokak ressamlarmı görüyor, ressam olmaya karar veriyor. Heykeltraşları izliyor ve nasıl bir his olduğunu deneyimleyebiliyor. Cehennemă̆zı Mağaralarında kendi yaşıtlarının piyano çaldığın görüyor. Bir benzeşim kuruyor" (Görüşmeci 3).

\section{Festivallerin Ekonomik Etkisi}

Katılımcıların hepsi festivallerin ekonomik yapıyı olumlu etkilediği yönünde görüş bildirmiştir. Genel değerlendirme festivallerin yerel halka katkı sağladığı, esnafın gündelik ticari yaşamını hareketlendirdiği yönündedir. 2 katılımcı ise festivallerin ekonomik etkisinin daha çok turizm sektörüne yönelik olduğunu belirtmiştir.

“... Şehir esnafinın gerek bölge ekonomisi gerekse firmalarının gelecekleri açısından bölgede yapılacak etkinlik ve festivalleri dört gözle beklediŭini söyleyebiliriz" (Görüşmeci 1).

“... Şehri ekonomik olarak toptan etkileyecek bir önemi olduğunu düşünmüyorum. Daha çok turizme (yeme-içme-barınma ve eğlenme) dayalı sektörlerde kısmen de olsa yukarı doğru bir hareketlenmeden söz edilebilir. Öte yandan büyük sektörlerin (otomotiv-inşaat-mobilya gibi) stantlarda yer alması daha doğru olur" (Görü̈smeci 3). 
“... Otellerde 5 günlük festival boyunca yer kalmadı. Misafirhanelerden ve konukevlerinden yararlanmak zorunda kaldık. Gelen misafirlerimizden bazılarını konukevlerine ve misafirhanelere yerleştirdik. Ayrıca gelenler yakın illerden ya da ilçelerden de oldu. Otoparklar farklı illerin plakalart ile doluydu. Bu bile ekonomik katkısının ne kadar fazla olduğunu göstermez mi?" (Görüşmeci 6).

"Esnafa çok ciddi bir katkısı oluyor. Festival boyunca su satandan, taksilere, manavdan, marketlere, restoranlardan otellere herkes kazanıyor" (Görüşmeci 7).

\section{Festivallerin İlçenin Gelişimine Etkisi}

Katılımcılar, festivallerin ilçenin gelişmesine olumlu bir katkısı olduğu yönünde hemfikir olmuşlardır. Festival ve etkinlikler boyunca birçok tarihi yerin gezildiğini, yeni yerlerin ziyaret edildiğini, yöresel yemeklerin yendiğini ve ilçenin tanınırlığın arttığını söylemişlerdir. Genel kanı turizm potansiyelinin gelişmesi ve ilçenin bilinir olması şeklindedir.

"...Bölgede yapılacak festival ve etkinlikler ilçede turizm potansiyelinin gelişmesine direk katkı sağlayacaktır. Etkinlikler kapsamında bölgeye gelen yerli-yabancı turistlere bölgenin turizm değgerlerini ön plana çıkartacak faaliyetlerin planlanması da orta-uzun vadede olumlu bir çalışma olacaktır" (Görüşmeci 5

“...Şehrin arz edilen ürün ve hizmetlerinin tanıtımında çokönemli katkı sağlamaktadır. Sanayi şehri olarak anılan ancak çok önemli turizm potansiyelini barındıran, henüz atıl halde bulunan değerlerin festival sayesinde gündeme gelmesi önemlidir. Dışarıdan gelen yerli-yabancı turistlerin bunların farkında olması turizme eşsiz, pratik ve ekonomik katkı sağlıyor" (Görüşmeci 2).

\section{Festivallerin İmaja Etkisi}

Katılımclar festival ve etkinliklerin imaj yaratmada, olumsuz imajı olumlu imaja dönüştürmede, ilçenin ismini duyurmasına katkı sağlamada etkili olduğunu düşünmektedirler. 1 katılımcı kişilerin yıllık tatillerini ilçede yapılan festivallere göre belirlediklerini eklemiştir. 3 katılımcı ilçe hakkında duman, is, karanlık gibi algıları olan kişilerin bu algılarının festivallerle değiştiğini belirtmiştir.

“...Düzenlenen festivallerle etkinliklerle kentimizin olumlu imajı desteklenmektedir. Kentimizin popülerliğini sağlamaktadır. Sosyo-kültürel olarak tanınması açısından festivallerin ve etkinliklerin sürekliliğine katkı sağlamak çok önemli" (Görüşmeci 5).

“...Ereğli'nin kara dumanlarla kaplıymış gibi düşünülen havasının aslında öyle olmadığını, denizinin Ege sahilleri ile yarışabilir nitelik taşıdığı, geceleri rahatça kadınların ve çocukların dolaşabileceği bir yer olduğu imajına katkı sağlıyor" (Görüşmeci 7).

“...Birçok yerde burada yapılan festivaller sayesinde adımizı duyuruyoruz. Ulusal ve yerel basında bir sürü haber yapılıyor. İnsanlar buranın nasıl bir yer olduğunu festivalle görebiliyor" (Görüşmeci 8).

\section{Festivallerin Tanıtıma Etkisi}

Festivallerin Ereğli ilçesinin bilinirliliğini sağladığı, festival ve etkinliklerle yerel tatların tanıtıldığı, turistik merkezlerin ziyaretçiler tarafından gezildiği, ulusal, uluslararası basında haberlere konu olduğu gibi sebeplerle katılımclar tarafından festivallerin tanıtım üzerinde olumlu etkisi olduğu görüşü hâkimdir. 
“...Doğru planlama, güncel konu ve konuklar, bölgesel değerlerin ön plana çıkartılabileceği organizasyonlar, turizm çekiciliği olan yerlerin önemli misafirlerle ziyaretlerinin sağlanması vb. hususlara yönelik çalışmalar, ilçenin tanıtımında rol oynuyor" (Görüşmeci 5).

“... Festivaller ve etkinliklerle nüfus 750.000'e kadar çıkıyor. 1400 sitenin yurt içi ve yurt dışı bazlı olmak üzere haber yaptığını biliyoruz. Bu yüzden festivaller Ereğli'yi anlatıyor ve öne çıkarıyor" (Görüşmeci 9).

\section{Festivallerde Kullanılan Tanıtım Araçları}

Katılımcılar genel olarak sosyal medyanın kullanılması, TV haberleri ve billboard reklamlarının tanıtım amaçlı kullanıldığını belirtmiştir. Katılımcıların geneli sosyal medyanın aktif olarak kullanılmasının Youtube, Instagram ve Facebook gibi sosyal ağlardan anlık paylaşımların yapılmasını önemli bulmuştur.

“...Etkinliklerin tanıtımında en etkin yol günümüzde internet haber siteleri, sosyal medyada organize eden kurumun oluşturduğu sayfalar ve SMS ile telefonlara gönderilen mesajlar hayli etkili oluyor. Birde şehir merkezlerinde ve otobüs duraklarmda faaliyet haberleri içeren billboardlar etkili oluyor" (Görüşmeci 4).

“...Sosyal ağları çok yoğun olarak kullandık. İnsanlar artık her şeye daha kolay ve çabuk ulaşmak istiyorlar. Bu yüzden sosyal medya ekibi oluşturarak buna önem verdik. Festival boyunca takipçi sayımızı paylaşımlarla arttırdık. Gelen etkileşimleri görmek, anında değerlendirmek anlamında sosyal medya çok yol gösterici oldu" (Görüşmeci 2).

\section{SONUÇ ve ÖNERILER}

Etkinlik ve festivaller destinasyonların gelişimi, yerel halkın sosyo-kültürel anlamda kendini ispatlayabilmesi ve anlamlandırabilmesi açısından önem taşımaktadır. Bu çalışmanın sonuçlarından biri olan festivallerin sosyo-kültürel yaşamı olumlu yönde etkilemesinden hareketle festivaller şehirlerin canlanmasını ve hareketlenmesini sağlamaktadır. Bunun yanı sıra hoşgörü ortamı oluşturarak farklı yapıdaki bireyleri ortak paydada buluşturmaktadır. $\mathrm{Bu}$ konuda yapılan araştırmalarla (Nagy ve Nagy, 2013) elde edilen bu sonuç benzerlik göstermektedir.

Araştırmanın bir diğer sonucu etkinlik ve festivallerin ekonomik hayata olumlu etki etmesidir. Etkinlik ve festivaller boyunca artan ziyaretçi sayısı ile birlikte her sektörde bir canlanma oluşmaktadır. Bu canlanmayla birlikte yerel halkın ve işletmecilerin refah düzeyinde artış meydana gelmektedir Sullivan ve Jackson (2002) ve Robertson vd., (2009) tarafından yapilan çalışmalarda da benzer sonuçlara ulaşılmıştır. Etkinlik ve festivallerin sosyal ve kültürel katkılarının yanında ekonomik katkısının da yadsınamaz olduğu belirtilmiştir.

Etkinlik ve festivaller destinasyonların çekim merkezi olmalarını sağlamaktadır. Çalışmanın sonuçlarından biri de bu yargıyı doğrular niteliktedir. Elde edilen bulgular aracılı̆̆ıyla Karadeniz Ereğli'deki turistik ve tarihi yerlerin festival döneminde sıklıkla ziyaret edildiği, farklı illerden gelen kişilerce ziyaret edildiği görülmüştür. Çalışmanın, etkinlik ve festivallerin bilinirliliği arttırması, çekim merkezi oluşturması sonucu diğer çalışmalarla örtüşür nitelik taşımaktadır. Kim ve Uysal'ın (2003) bu konuda yaptıkları çalışmada da benzer sonuçlara ulaşılmıştır.

Çalışmadan elde edilen sonuçlardan bir diğeri etkinliklerin ve festivallerin ilçe imajını olumlu yönde etkilediği yönünde olmuştur. Özellikle endüstriyel yapısıyla anılan ve bu imajı oluşturan ilçenin etkinlik ve festivaller aracılığıyla bu imajı değiştirmesi önemli bir unsurdur. Görüşmeler esnasında elde edilen veriler, festival boyunca görevliler aracılığıyla ziyaretçilerden alınan geri bildirimlerin olumlu olduğunu göstermiştir. Özellikle bireylerin zihinlerindeki Ereğli ile 
deneyimledikleri arasında farklılıklar olduğu, olumlu izlenimlerle ilçeden ayrıldıkları belirtilmiştir. Buradan hareketle etkinlik ve festivaller ile Karadeniz Ereğli imajının olumsuz bir imajdan olumlu bir imaja dönüşmesinde etkin bir rol oynadığ şeklinde çıkarım yapmak mümkündür.

Çalışmada etkinlik ve festival boyunca medyanın etkin bir biçimde kullanıldığı görülmüştür. Faaliyetler öncesinde ve süresince daha fazla ziyaretçi çekebilmek adına tanıtımlar yapılmıştır. Ulusal ve uluslararası basın organları ve sosyal medya araçları tanıtım araçları olarak kullanılmıştır. Özellikle sosyal medya araçlarından faaliyetler boyunca canlı yayınlar yapılmıştır.

Çalışma kapsamında elde edilen tüm sonuçlar etkinlik ve festivallerin olumlu etkileri üzerine yoğunlaşmıştır. Bu tip faaliyetlerin çeşitlenmesi ve sıklaştırılması gerekliliği belirtilmiştir. Etkinlik ve festivallerin sosyo-kültürel anlamda ve ekonomik anlamda canlılık sağladığı, bireyleri bir arada tuttuğu, birleştirici gücü olduğu ve hoşgörü ortamı yaratması bu düşüncenin hakim çıkış noktası olmuştur.

\section{KAYNAKÇA}

Arnegger, J. and Herz, M. (2016). Economic and Destination Image Impacts of Mega-Events in Emerging Tourist Destinations, Journal of Destination Marketing \& Management, 5: 76-85.

Babacan, E. ve Göztaş, A. (2011). Etkinlik Yönetimi, Ankara: Detay Yayıncllı.

Bogan, E., Constantin, D. M., Roanghes-Mureanu, A. M., Grigore, E. and Dirloman, G. (2017). The Role of Festivals in Developing and Promoting the Urban Tourism in the Bucharest Municipality, Academic Journal of Economic Studies, 3(4): 12-18.

Cizmic, E. and Causevic, A. (2017). Impact of Event Tourism in a Tourist Destination Quality of Experience - Case of the Sarajevo Film Festival, Universal Journal of Management, 5(7), 332-340.

Congcong, T. (2014). The Study of Festival Tourism Development of Shanghai, International Journal of Business and Social Science, 5(4): 52-58.

Çelik, S. and Çetinkaya, M. Y. (2013). Festivals in Event Tourism: The Case of International İzmir Art Festival, International Journal of Contemporary Economics and Administrative Sciences, 3(1):1-21.

Çulha, O. (2008). Kültür Turizmi Kapsamında Destekleyici Turistik Ürün Olarak Deve Güreşi Festivalleri Üzerine Bir Alan Çalışması, Journal of Yasar University, 3(12): 1827-1852.

Erdem, Ö., Mızrak, M. ve Aratoğlu, C. (2018). Festivallerin Bölge Turizmine Katkıları ve Sürdürülebilirliği: Uluslararası Mengen Aşçılık ve Turizm Festivali Örneği, Journal of Tourism and Gastronomy Studies, 6(1): 228-245.

Felsenstein, D. and Fleischer, A. (2003). Local Festivals and Tourism Promotion: The Role of Public Assistance and Visitor Expenditure, Journal of Travel Research, 41: 385-392.

Getz, D. (2008). Event Tourism: Definition, Evolution and Research, Tourism Management, 29: 403428.

Getz, D. and Page, S. J. (2016). Progress and Prospects for Event Tourism Research, Tourism Management, 52: 593-631.

Karabağ, S. F., Yavuz, M. C. and Berggren, C. (2011). The Impact of Festivals on City Promotion: A Comparative Study of Turkish and Swedish Festivals, Original Scientific Paper, 59(4): 447-464.

Kim, K. and Uysal, M. (2003). Perceived Socio-Economic Impacts of Festivals and Events Among Organizers, Journal of Hospitality \& Leisure Marketing, 10(3/4): 159-171. 
Laing, J. (2018). Festival and Event Tourism Research: Current and Future Perspectives, Tourism Management Perspectives, 25: 165-168.

Mihajlovic, I. and Vidak, M. (2017). The Importance of Local Events for Positioning of Tourist Destination, European Journal of Social Sciences, 4(4): 228-239.

Mohammad, B. A. A. (2014). Festival Tourism in Saudi Arabia: A Study of Image and Motivation of Participating in Janadriyah Festival, American Journal of Tourism Management, 3(2): 45-54.

Nagy, A. and Nagy, H. (2013). The Importance of Festival Tourism in the Economic Development of Hungary, Visegrad Journal on Bioeconomy and Sustainable Development, 2(2): 57-59.

Nakip, M. (2013). Pazarlamada Araştırma Teknikleri, Ankara: Seçkin Yayıncılık.

Okech, R. N. (2011). Promoting Sustainable Festival Events Tourism: A Case Study of Lamu Kenya, Worldwide Hospitality and Tourism Themes, 3(3): 193-202.

Penpece, D. (2014). Festivallerin Pazarlanması: Türkiye'deki Uluslararası Festivaller Üzerinde Bir Araştırma, Ç. Ü. Sosyal Bilimler Enstitüsü Dergisi, 23(1): 193-210 193.

Robertson, M., Rogers, P. and Leask, A. (2009). Progressing Socio-Cultural Impact Evaluation for Festivals, Journal of Policy Research in Tourism, Leisure and Events, 1(2): 156-169.

Sullivan D. and Jackson, M. J. (2002) Festival Tourism: A Contributor to Sustainable Local Economic Development?, Journal of Sustainable Tourism, 10(4): 325-342.

Timur, M. N., Çevik, S. ve Kıyık-Kıcır, G. (2014). Etkinlik Turizmi: Kültür Başkenti Etkinliklerinin Başarı Unsurları Üzerine Bir Değerlendirme, Akademik Sosyal Araştırmalar Dergisi, 2(2/1): 56-83.

Tümbek-Tekeoğlu, A. N. ve Gökseven, K. (2019). Bir Şehrin Festivaller ile Markalaşması ve Pazarlanması Olarak Adana'nın İncelenmesi, TURAN-SAM Uluslararası Bilimsel Hakemli Dergisi, 11(42): 345-357.

Yıldırım, M. ve Çevik, S. (2017). Etkinlik Turizminin Sağladığı Faydalar Açısından Erdek Zamanı Festivali Katılımclarının Memnuniyet Düzeylerinin Belirlenmesi, Route Educational and Social Science Journal, 4(7): 241-251.

Yolal, M. (2017). Türkiye'nin Etkinlik Turizmi Potansiyelinin Değerlendirilmesi, Uluslararası Turizm ve Sosyal Araştırmalar Dergisi, 2: 35-51. 